\title{
Effect of the antifreeze protein on the microstructure of strawberries (Fragaria ananassa Duch)
}

\section{Efeito da proteína anticongelante sobre a microestrutura do morango (Fragaria ananassa Duch)}

\author{
Marilene da Silva Rosa1 ${ }^{1}$ Chirle Ferreira², João Gustavo Provesi ${ }^{3}$, \\ Edna Regina Amante ${ }^{4 *}$ (D)
}

\author{
${ }^{1}$ Universidade Federal de Santa Catarina (UFSC), Departamento de Ciência e Tecnologia de Alimentos, \\ Florianópolis/SC - Brasil \\ ${ }^{2}$ Universidade Federal de Santa Catarina (UFSC), Biologia, Florianópolis/SC - Brasil \\ ${ }^{3}$ Instituto Federal de Santa Catarina (IFSC), Tecnologia de Alimentos, Urupema/SC - Brasil \\ ${ }^{4}$ Universidade Federal de Santa Catarina (UFSC), Departamento de Ciência e Tecnologia de Alimentos, \\ Florianopolis/SC - Brasil
}

*Corresponding Author: Edna Regina Amante, Universidade Federal de Santa Catarina (UFSC), Departamento de Ciência e Tecnologia de Alimentos, Rodovia Admar Gonzaga, CEP: 88034000, Florianopolis/SC - Brasil, e-mail: e.amante@ufsc.br

Cite as: Rosa, M. S., Ferreira, C., Provesi, J. G., \& Amante, E. R. (2019). Effect of the antifreeze protein on the microstructure of strawberries (Fragaria ananassa Duch). Brazilian Journal of Food Technology, 22, e2018218. https://doi.org/10.1590/1981-6723.21818

\begin{abstract}
The present work aimed to evaluate the effect of the antifreeze protein on the microstructure and physicochemical properties of hidroponic strawberries, evaluating the titratable acidity, $\mathrm{pH}$, colour and optical microscopy before freezing both in natura (IN) and impregnated with the protein (IP), and after thawing without the protein (TWP) and impregnated (TIP) with the antifreeze protein (AFP Type I from fish) by vacuum impregnation. After thawing, the treatment was also compared in terms of drip losses. The antifreeze protein impregnated strawberries showed no statistical differences with respect to the physicochemical properties, but the drip loss was statistically lower from the thawed strawberries treated with the antifreeze protein. The vacuum impregnated thawed strawberries showed less damage to the microstructure. The cells of the thawed samples with antifreeze protein conserved the structure of the reference samples of in natura strawberry.
\end{abstract}

Keywords: Strawberry; Vacuum impregnation; Freezing; Microstructure.

\section{Resumo}

O presente trabalho tem o objetivo de elucidar o efeito da proteína anticongelante sobre a microestrutura e as propriedades físico-químicas do morango hidropônico, avaliado quanto a acidez titulável, pH, cor e microscopia ótica, antes do congelamento, in natura (IN) e impregnado com proteína anticongelante (IP), depois do descongelamento sem proteína (TWP) e impregnado (TIP) com proteína anticongelante (AFP), tipo I de pescado, por impregnação a vácuo. Após o descongelamento, o tratamento foi também comparado quanto à perda por gotejamento. Morangos impregnados com proteína anticongelante não apresentaram diferença estatística quanto 
às propriedades físico-químicas; no entanto, a perda por gotejamento foi estisticamente menor nos morangos descongelados tratados com proteína anticongelante. Foi possível observar menores danos na microestrutura do morango descongelado que sofreu impregnação a vácuo. As células das amostras descongeladas que foram impregnadas com proteína anticongelante conservaram a estrutura observada nas amostras de referência de morango in natura.

Palavras-chave: Morango; Impregnação a vácuo; Congelamento; Microestrutura.

\section{Introduction}

Water constitutes about 80 to $95 \%$ of the composition of fruits and vegetables (Chitarra \& Chitarra, 2005). When immobilized by lowering the temperature to the freezing point, crystals are formed and the structure becomes solid due to transformation of the liquid water into ice (Fellows, 2006).

The possibility of exerting control over the behaviour of ice after its formation has always been a challenge to researchers in diverse areas. Studies on the use of cryoprotectant additives are easily found in the literature, but it is usually necessary to use these substances in high concentrations, which makes it impossible to use them in most foods (Provesi \& Amante, 2015).

The establishment of methodologies that reduce the size of ice crystals and reduce or inhibit the phenomena of recrystallization can have an extraordinary significance on the final quality of frozen products and, consequently, create new market opportunities (Cruz et al., 2009).

The use of antifreeze proteins in fruits can contribute to the expansion of the applications by minimizing the damage caused during freezing. Strawberry is a widely accepted fruit and freezing strawberries is a longterm preservation method that allows for their application in processed foods throughout the whole year, such as in jams, juices or fruit preparations, for instance, not limiting their consumption to seasonality, and ensuring a constant supply to the market and in order to satisfy the consumer (Oszmianski et al., 2009).

This work aimed to evaluate the effects of antifreeze proteins on the microstructure and physicochemical characteristics of strawberries grown in a hydroponic system.

\section{Materials and methods}

The strawberries (Fragaria ananassa Duch) were obtained from the of Hydroponics Laboratory (LabHidro) of the Federal University of Santa Catarina (UFSC), Florianópolis, Santa Catarina, Brazil. Samples of similar size (average height of $4.4 \pm 2.6 \mathrm{~cm}$ and diameter of $3.3 \pm 2.5 \mathrm{~cm}$ ) and degree of ripeness (red colour intensity) were selected, hand-picked with gardening scissors and placed in a polyethylene container.

The antifreeze protein, Type I AFP, from fish, was purchased from A/F Protein Inc. (Boston/USA), containing $50 \%$ protein.

\subsection{Preparation of the samples}

The strawberries were cleaned under running water to remove dirt, dried with paper towels and the sepals removed with the aid of a stainless steel knife. The samples were submitted to the following treatments: $\mathrm{IN}=$ in natura IP = infiltrated with protein; TWP = thawed without protein; TIP = thawed infiltrated with protein. 


\subsection{Vacuum impregnation}

Vacuum impregnation was based on the methodology described by Cruz et al. (2009), in which a solution with $0.02 \mathrm{~g} / \mathrm{L}$ antifreeze protein is dipped into ultra-pure water (Millipore, Simplicity, France) in a vacuum system. The vacuum impregnation system was composed of a vacuum pump (Prismatec, 132 model, Brazil), a vacuum glass desiccator and a ceramic support to maintain the fruits submersed. Vacuum infiltration was carried out at from 525 to $550 \mathrm{mmHg}$ (around 70 to $73 \mathrm{kPa}$ ), for $15 \mathrm{~min}$, and the vacuum briefly interrupted at 5 min intervals to increase infiltration of the solution into the fruit matrix. For the immersion treatment the application time was also $15 \mathrm{~min}$.

\subsection{Freezing and thawing}

The strawberries were frozen without protein and after vacuum impregnation with the protein and maintained in a vertical freezer (Electrolux, FE22, Brazil) for a period of 45 days at a temperature of $-22{ }^{\circ} \mathrm{C}$. During the thawing process, the groups of strawberries were placed individually in identified funnels capped with PVC film, and placed in conical flasks. These set-ups were placed on a bench at a room temperature of $25^{\circ} \mathrm{C}$ for $2 \mathrm{~h}$, and then placed in a refrigerator (Electrolux, RW34, Brazil) overnight (Velickova et al., 2013). The assays were carried out with four replicates.

\subsection{Physicochemical characteristics}

The physicochemical characteristics were determined according to the recommendations described by the Adolfo Lutz Institute (Brasil, 2008). Pulps were prepared using strawberries from each of the following treatments: in natura (IN), protein impregnated (IP), thawed without protein (TWP) and thawed impregnated with protein (TIP). For pulp production, the strawberries from each group were ground in a mixer (Walita/Viva-RI1364, Brazil).

The soluble solids contents were determined using a previously calibrated Abbé (Carl Zeiss Jena, Tropenmodell I, Germany) refractometer. The $\mathrm{pH}$ values were determined by direct immersion of the electrode of a previously calibrated $\mathrm{pH}$ meter in $10 \mathrm{~g}$ of pulp (Quimis, Q-400 A, Brazil).

The titratable acidity of each pulp was determined with the aid of a pH meter (Quimis, Q-400 A, Brazil), by direct titration with a $0.1 \mathrm{~mol} \mathrm{~L}^{-1}$ solution of sodium hydroxide to the $\mathrm{pH}$ range between 8.2-8.4. The results were calculated in terms of citric acid.

\subsection{Drip loss - drip}

The thawed strawberries were weighed on an analytical balance (Bel Engineering, Italy) and the drip loss calculated using Equation 1.

$m_{\text {driploss }}=\frac{m_{1-m_{2}}}{m_{1}} \times 100$

Where $m_{1}$ is the mass of the frozen strawberries and $m_{2}$ is the mass of the strawberries after thawing (Velickova et al., 2013).

\subsection{Effect of freezing on the colour of the strawberries}

The colour of the pulps was determined using a digital colorimeter (Konica Minolta, CR-400, Japan), which was calibrated using a standard whiteboard $(y=93.5, x=0.3164, y=0.3325)$. The parameters measured were based on the CIE colour scale system $(\mathrm{L} * \mathrm{a} * \mathrm{~b} *)$. The analyses were carried out in triplicate with four measurements of each sample. 


\subsection{Microscopy}

Samples of fresh strawberries (IN) and of those submitted to freezing at $-22{ }^{\circ} \mathrm{C}$ for 45 days and thawed according to the methodology of Velickova et al. (2013) (TWP), and thawed samples of those impregnated with antifreeze protein (TIP) were transported in polystyrene boxes to the Multiuser Laboratory of Studies in Biology (LAMEB), CCB, UFSC, Santa Catarina, Brazil. Slices were prepared from the upper and bottom parts of the strawberry, since, considering that the sepals had already been removed, the upper part would theoretically show greater protein impregnation. The upper part was sectioned into four parts, of which $1 / 4$ was used in the preparation of a slice with approximately $2 \mathrm{~mm}$ in thickness. After sectioning, the bottom of the fruit was maintained whole and approximately $2 \mathrm{~mm}$ thick.

The TLM (Transmitted Light Microscopy) analysis was carried out according to the methodology described by Oliveira \& Akisue (2009), with modifications. The material was fixed with a $2.5 \%$ glutaraldehyde solution in $0.1 \mathrm{~mol} \mathrm{~L}^{-1}$ sodium phosphate buffer ( $\mathrm{pH} 7.2$ ) for 24 hours. After fixation, the samples were washed three times in the same buffer (30 minutes each wash), and dehydrated in ethanol solutions of increasing concentration (30,50,70, 90 and 100\%), changing the solution at 30-minute intervals, and repeating the dehydration in $100 \%$ ethanol twice. The material was subsequently diaphanized in $50 \%$ xylol and $100 \%$ xylol for 1 hour each, for inclusion in paraffin, a process which took 18 hours, with 6 hours in each paraffin (I, II and III) carried out in the sample processor (Leica, TP1020, Germany). The paraffin blocks containing the samples were prepared in the sample hopper according to the manufacturer's instructions (Jungs-Leica) (Leica, EG1150H, Germany). After 24 hours, $5 \mu \mathrm{m}$ thick sections were prepared in a microtome (Leica, RM2255, Germany) and arranged on slides for the cytochemical test.

Astra blue and fuchsin were used for the morphological and anatomical analyses. Cytochemistry was carried out according to the method of Kraus et al. (1998), with modifications.

At the end of the cytochemical tests, the slides with the stained sections were sealed with Canada Balm mounting medium and covered with a cover slip. The material was analysed and photographed using a slide scanner (Zeiss, Axio Scan Z1, Germany) on LAMEB. The microscopic images were edited using CorelDRAW software (Corel, 2017).

\subsection{Statistical analysis}

Except where otherwise cited, all the analyses were carried out in triplicate and the results expressed as the mean \pm standard deviation. They were submitted to an analysis of variance (ANOVA) and means comparison test using Tukey's multiple-range test $(p \leq 0.05)$ in order to compare the groups. The ANOVA assumptions, such as independence and normal distribution of the residues and homogeneity of the variances, were observed in all the statistical analyses.

\section{Results and discussion}

\subsection{Physicochemical characteristics}

There was no statistically significant difference $(p>0.05)$ between the treatments, before and after treatment, with respect to the total soluble solids (Brix) (Table 1). 
Table 1. Total soluble solids ( $\left({ }^{\circ}\right.$ Brix corrected to $20^{\circ} \mathrm{C}$ ), $\mathrm{pH}$, total titratable acidity by potentiometric volumetry ${ }^{(1)}$ and citric acid content ${ }^{(2)}$ for samples without protein and for those with vacuum infiltrated protein before and after the freeze-thaw cycle.

\begin{tabular}{ccccc}
\hline Treatment & ${ }^{\circ}$ Brix & pH & TTA $^{(\mathbf{1})}(\mathbf{m L} / \mathbf{1 0 0 g})$ & $\begin{array}{c}\text { TTA }^{(\mathbf{2})} \\
(\mathbf{m g} / \mathbf{1 0 0 g})\end{array}$ \\
\hline IN & $3.49 \pm 0.08^{\mathrm{a}}$ & $3.27 \pm 0.12^{\mathrm{ab}}$ & $17.68 \pm 0.59^{\mathrm{a}}$ & $1,130 \pm 40^{\mathrm{a}}$ \\
IP & $3.82 \pm 0.15^{\mathrm{a}}$ & $3.30 \pm 0.09^{\mathrm{ab}}$ & $18.17 \pm 0.59^{\mathrm{a}}$ & $1,160 \pm 40^{\mathrm{a}}$ \\
TWP & $4.07 \pm 0.50^{\mathrm{a}}$ & $3.14 \pm 0.02^{\mathrm{b}}$ & $18.35 \pm 0.37^{\mathrm{a}}$ & $1,170 \pm 20^{\mathrm{a}}$ \\
TIP & $3.88 \pm 0.12^{\mathrm{a}}$ & $3.47 \pm 0.09^{\mathrm{a}}$ & $18.75 \pm 0.56^{\mathrm{a}}$ & $1,200 \pm 30^{\mathrm{a}}$ \\
\hline
\end{tabular}

Mean \pm Standard Deviation. TTA $=$ total titratable acidity; IN = in natura; IP = impregnated with protein; TWP = thawed without protein; $\mathrm{TIP}=$ thawed infiltrated with protein. Means followed by the same letters in the same column have F values not significant at the $5 \%$ significance level according to the analysis of variance. Means followed by different letters in the same column indicate a significant difference between the different treatments at the $5 \%$ level of significance according to the Tukey test.

Considering the Brazilian Technical Regulation of Identity and Quality for strawberry pulp of the Ministry of Agriculture, Livestock and Food Supply (MAPA), the minimum value for the ${ }^{\circ}$ Brix of strawberries is 7.50 at $20^{\circ} \mathrm{C}$, which is not compatible with the results obtained here, where the values were all lower (Brasil, 2016). This fact can be attributed to the state of maturation of the harvested fruit, despite its intense red colour. A comparison between the samples with respect to the values for Brix showed that vacuum impregnation did not significantly interfere with the soluble solids contents, or it could indicate excessive moisture impregnation, not determined in the present work.

No statistical difference was observed in the $\mathrm{pH}$ of the pulps $(p>0.05)$ (Table 1) when comparing the in natura strawberry with the protein impregnated one, as well as between the same samples after freezing and thawing. The results were similar for the in natura strawberries and those impregnated with the protein, before and after freezing and thawing, with no significant difference between the respective treatments. There was a significant difference in $\mathrm{pH}$ between the thawed strawberries with and without the protein. The $\mathrm{pH}$ value of the thawed strawberry without protein decreased, whereas that of the strawberry thawed with protein increased. This result can be attributed to cellular extravasation caused by freezing damage without the use of the protein.

In addition to the direct damage caused by ice crystals, several phenomena associated with the formation of these crystals occur during freezing, which also affect the quality of frozen foods, such as the increase in solutes concentration. The increase in concentration of the various solutes modifies the characteristics of the non-frozen fraction: $\mathrm{pH}$, ionic strength, redox potential etc. The effect of these changes depends, to a great extent, on their magnitude and the specific influence they have on the different components of the food (Provesi \& Amante, 2015; Reno et al., 2011).

According to Oetterer et al. (2006), one can observe a decrease in the ascorbic acid content of frozen fruit during storage, due to oxidation. The same was observed experimentally by Holzwarth et al. (2012), who obtained a reduction in the ascorbic acid content when the strawberries were submitted to freezing without cryoprotectants and thawed under refrigeration at $4^{\circ} \mathrm{C}$. In both cases, the action of oxidative enzymes occurred, which may interfere with the increase in $\mathrm{pH}$ observed for strawberries impregnated with the protein.

No significant differences were observed in the parameter of titratable acidity amongst the samples of fresh strawberry with and without the protein, and the thawed samples with and without the protein. From the values obtained for titratable acidity, one can calculate the acidity in terms of citric acid for the strawberry samples. The organic acids present in foods influence the taste, odour, colour, stability and quality maintenance.

No significant differences were observed in the citric acid acidity of the strawberry samples, with and without the antifreeze protein, before and after the freezing and thawing process. When comparing the results 
obtained for acidity in terms of citric acid with the values cited in the Technical Regulation of Identity and Quality for strawberry pulp of the Ministry of Livestock and Food Supply (MAPA), the minimum value for citric acid is $0.80 \mathrm{~g} / 100 \mathrm{~g}$ of sample, which is compatible with the results obtained here, which were all above the minimum value required by the legislation (Brasil, 2016).

\subsection{Drip loss - Drip}

The results obtained in the drip loss analysis (Table 2) showed a significant difference between the treatments, the thawed without protein sample showing the greatest drip loss. Red fruits are very susceptible to water loss and, according to Damodaran et al. (2010), even losses as small as 1\% in strawberries can result in significant loss of surface gloss. During freezing, the cells undergo collapse with liquid exudation, And on thawing, the damaged tissues lose their stiffness and appear soggy (Chitarra \& Chitarra, 2005). These facts may explain the greater drip loss observed.

Modifications in the functional properties of some food components may be limited by the use of cryoprotectants, although the mechanism of action is not fully understood. These compounds are capable of immobilizing water and preventing its crystallization. When cryoprotectants pass into the cell, they also prevent dehydration and denaturation of the cellular components (Pereda et al., 2005).

Table 2. Drip loss of protein-free and protein impregnated strawberry samples after the freeze-thaw cycle.

\begin{tabular}{cc}
\hline Treatment & Drip loss (g/100g) \\
\hline TWP & $15.74 \pm 2.15^{\mathrm{a}}$ \\
TIP & $5.63 \pm 1.06^{\mathrm{b}}$ \\
\hline
\end{tabular}

Mean \pm Standard deviation. TWP $=$ thawed without protein; TIP $=$ thawed impregnated with protein. Means followed by different letters in the same column indicate a significant difference between the different treatments at the $5 \%$ level of significance according to the Tukey test.

Changes in the volume of frozen foods were reported by Leniger and Beverloo (1975), apud Fellows (2006). Since the ice volume is $9 \%$ greater than the volume of pure water, an expansion of the food after freezing would be expected. However, the degree of expansion varies considerably due to certain factors such as the cellular arrangement, since plant products have intercellular spaces that absorb the internal increases in volume without major changes in their total size, for example, whole strawberries increase by $3.0 \%$, while crushed strawberries increase by $8.2 \%$ when frozen at $-20^{\circ} \mathrm{C}$. According to Pereda et al. (2005), this is the reason why cell rupture, cell separation and anomalous texture are usually observed in frozen plant foods.

The significant difference between the drip of the samples with and without the impregnation of the antifreeze protein is another indication that vacuum impregnation did not add moisture to the strawberries during the process, since the impregnated ones also presented a smaller drip loss.

\subsection{Effect on colour}

The colour of the untreated and treated strawberry pulps was evaluated and the results are presented in Table 3, which shows the mean values for the parameters $L *$ (luminosity), $a *$ (red) and b * (yellow).

It can be seen that the freezing process did not influence the values for $\mathrm{L}^{*}$, so there was no whitening or darkening of the strawberry pulps, since there was no significant increase or decrease in luminosity when comparing the non-frozen samples with the frozen and thawed samples. The changes in colour are considered as the main criterion for judging fruit maturity by the consumer.

In general, all the samples were in the red region for the parameter a ${ }^{*}$, which refers to the green $(-) /$ red $(+)$ colours, since all the values were positives. There was no difference in the a* values for the strawberry 
pulps before and after thawing, except for the in nature strawberry and that frozen with the antifreeze protein (TIP), which showed increases in the parameter a *. This was because the antifreeze protein provides for the formation of small ice crystals, and thus less damage occurred to the cells, resulting in less diffusion of the pigment. Holzwarth et al. (2012) also observed this result.

In general, all the values for $\mathrm{b} *$ were positive and hence fitted into the yellow region. There was no difference between the thawed strawberries with and without the protein, but the $b$ * values of both increased when compared to the strawberry pulps before freezing. Koblitz (2008) stated that anthoxanthins are pigments that are easily oxidized by oxygen from the air with the formation of yellowish brown products.

The main action of the oxidative enzymes in strawberry is directly related to the degradation of fruit colour, and the main enzyme responsible for the degradation of anthocyanins in strawberries is polyphenoloxidase (PPO) (Chisari et al., 2007).

Table 3. Colour parameters of the strawberry samples with and without vacuum impregnated protein before and after the freezing and thawing cycle.

\begin{tabular}{ccccc}
\hline \multirow{2}{*}{ Parameters } & \multicolumn{4}{c}{ Samples } \\
\cline { 2 - 5 } & IN & IP & TWP & TIP \\
$\mathrm{L}^{*}$ & $32.98 \pm 3.29^{\mathrm{a}}$ & $31.54 \pm 2.04^{\mathrm{a}}$ & $38.18 \pm 4.73^{\mathrm{a}}$ & $37.20 \pm 1.76^{\mathrm{a}}$ \\
$\mathrm{a}^{*}$ & $26.82 \pm 1.06^{\mathrm{b}}$ & $29.10 \pm 0.60^{\mathrm{ab}}$ & $31.84 \pm 4.83^{\mathrm{ab}}$ & $33.59 \pm 0.69^{\mathrm{a}}$ \\
$\mathrm{b}^{*}$ & $12.85 \pm 2.18^{\mathrm{b}}$ & $14.04 \pm 1.64^{\mathrm{b}}$ & $21.16 \pm 1.61^{\mathrm{a}}$ & $21.97 \pm 2.84^{\mathrm{a}}$ \\
\hline
\end{tabular}

Mean \pm Standard Deviation. IN = in natura; IP = impregnated with protein; TWP = thawed without protein; TIP = thawed impregnated with protein. Means followed by the same letters in the same column have $\mathrm{F}$ values that are not significant at the $5 \%$ significance level according to the analysis of variance. Means followed by different letters in the same column indicate a significant difference between the different treatments at the $5 \%$ level by the Tukey test.

It was verified that the change in colour attributes was related to factors arising from the way the strawberries were treated and subsequently subjected to freezing. Treatment with the use of antifreeze proteins avoided breakdown of the chloroplasts and degradation of the chlorophylls, as well as avoiding a change in the colour of the anthocyanins due to the $\mathrm{pH}$ change caused by the precipitation of salts in concentrated solutions.

The variation in the colours and forms of the anthocyanins is $\mathrm{pH}$ dependent, as reported by Koblitz (2008), which may have influenced the colour parameters obtained in this work, since in an acidic environment the anthocyanins are present in the form of oxonium salts and usually have bright red colours.

Even at freezing temperatures, enzymatic reactions may occur. Moreover, if the membranes of the cellular organelles (mitochondria or lysosomes) are damaged during freezing, the release of the enzymes contained in them and their contact with their substrates may favour the initiation of enzymatic reactions (Pereda et al., 2005; Damodaran et al., 2010).

\subsection{Effect of freezing on strawberry microstructure}

When observing the images of the microscopies referring to in this study, a great difference between the samples can be noted (IN), (TWP) and (TIP) (Figures 1, 2 and 3). 


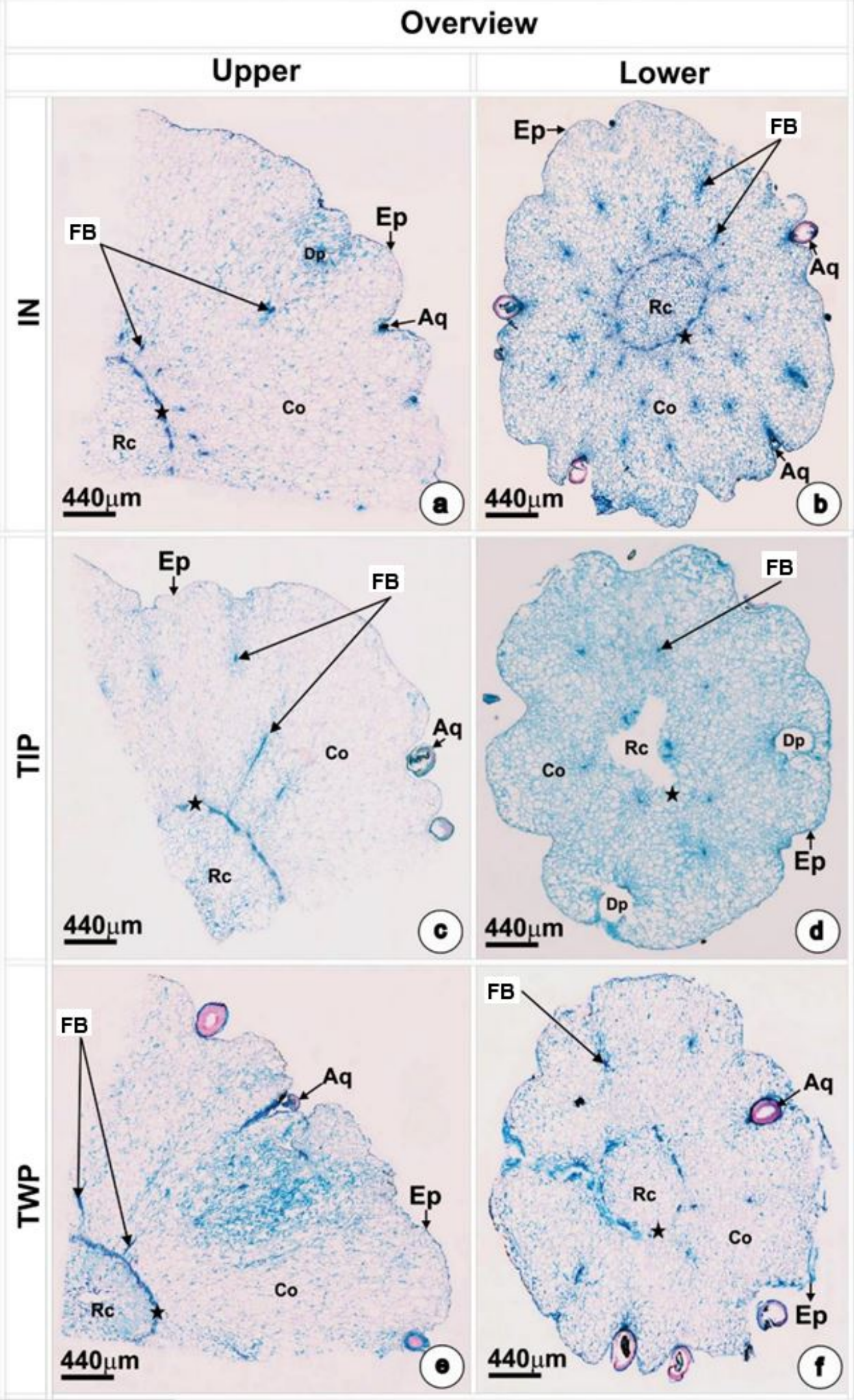

Figure 1. Overview of the upper and lower sections of the in natura strawberries, with and without impregnation with antifreeze protein. a-f. Photomicrographs of strawberry transverse sections treated with Astra Blue (with primary blue wall) and Fuchsin (with secondary pink wall), fresh samples (a-b), samples impregnated with antifreeze protein (c-d), and samples without antifreeze protein (e-f). Samples a, c, and e are from the upper part and b, $d$ and $f$ are from the bottom. Caption: Aq -achene; Co - cortex; Dp - depression; Ep - epidermis; FB - vascular bundle; IN - in natura; TIP - thawed infiltrated with protein; TWP - thawed without protein. 


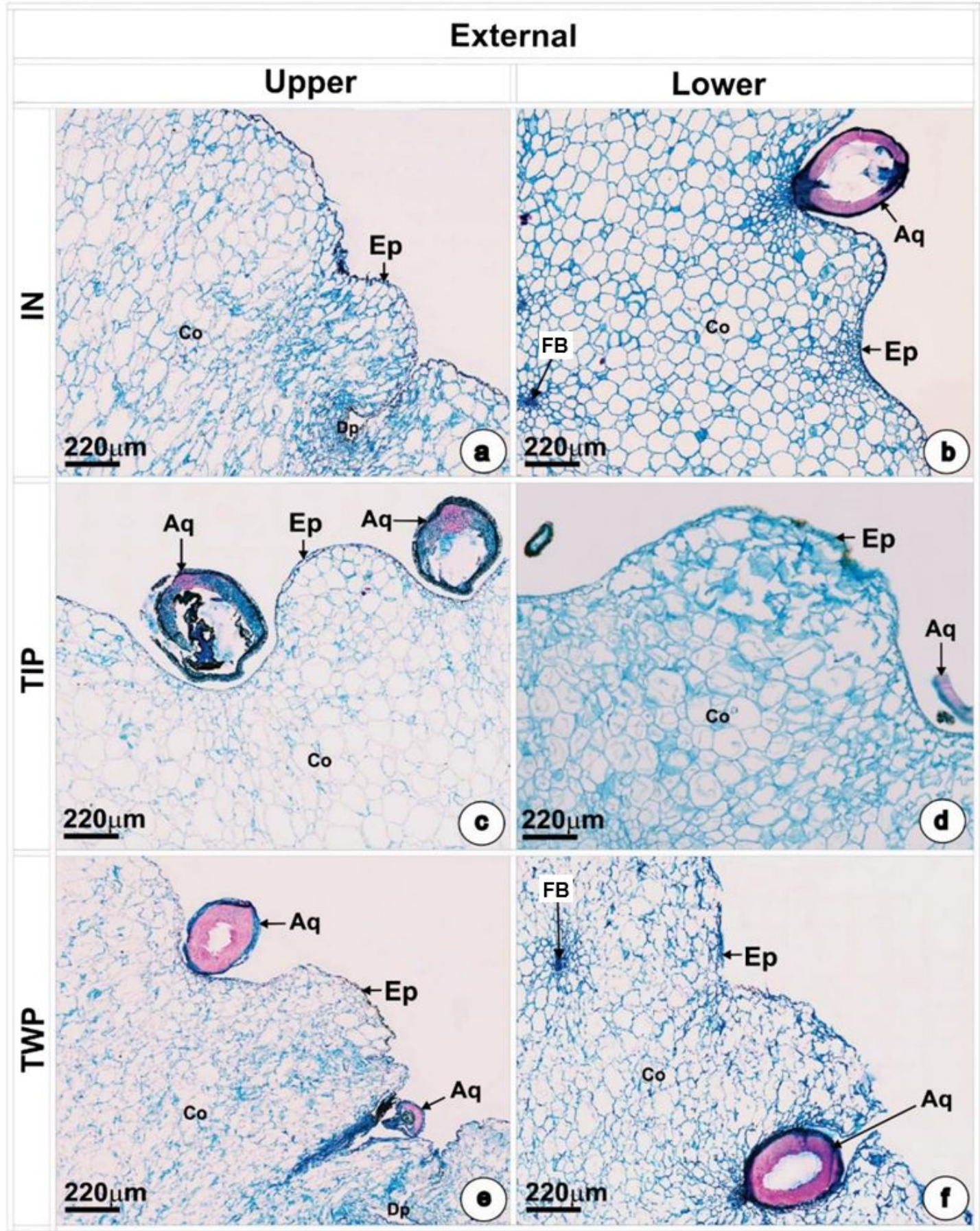

Figure 2. Eternal view of the upper and lower sections of the in natura strawberry, with and without impregnation with antifreeze protein. a-f. Photomicrographs of strawberry transverse sections treated with Astra Blue (With primary blue wall) and Fuchsin (with secondary pink wall), fresh samples (a-b), samples impregnated with antifreeze protein (c-d), and samples without antifreeze protein (e-f). Samples a, c, e are from the upper part and samples $\mathbf{b}, \mathbf{d}$ and $\mathbf{f}$ are from the lower part. Caption: Aq achene; Co - cortex; Ep - epidermis; FB - vascular bundle; Rc - central region; Star $(\star)$ - narrow zone of vascular bundle; IN - in natura; TIP - thawed infiltrated with protein; TWP - thawing without protein. 


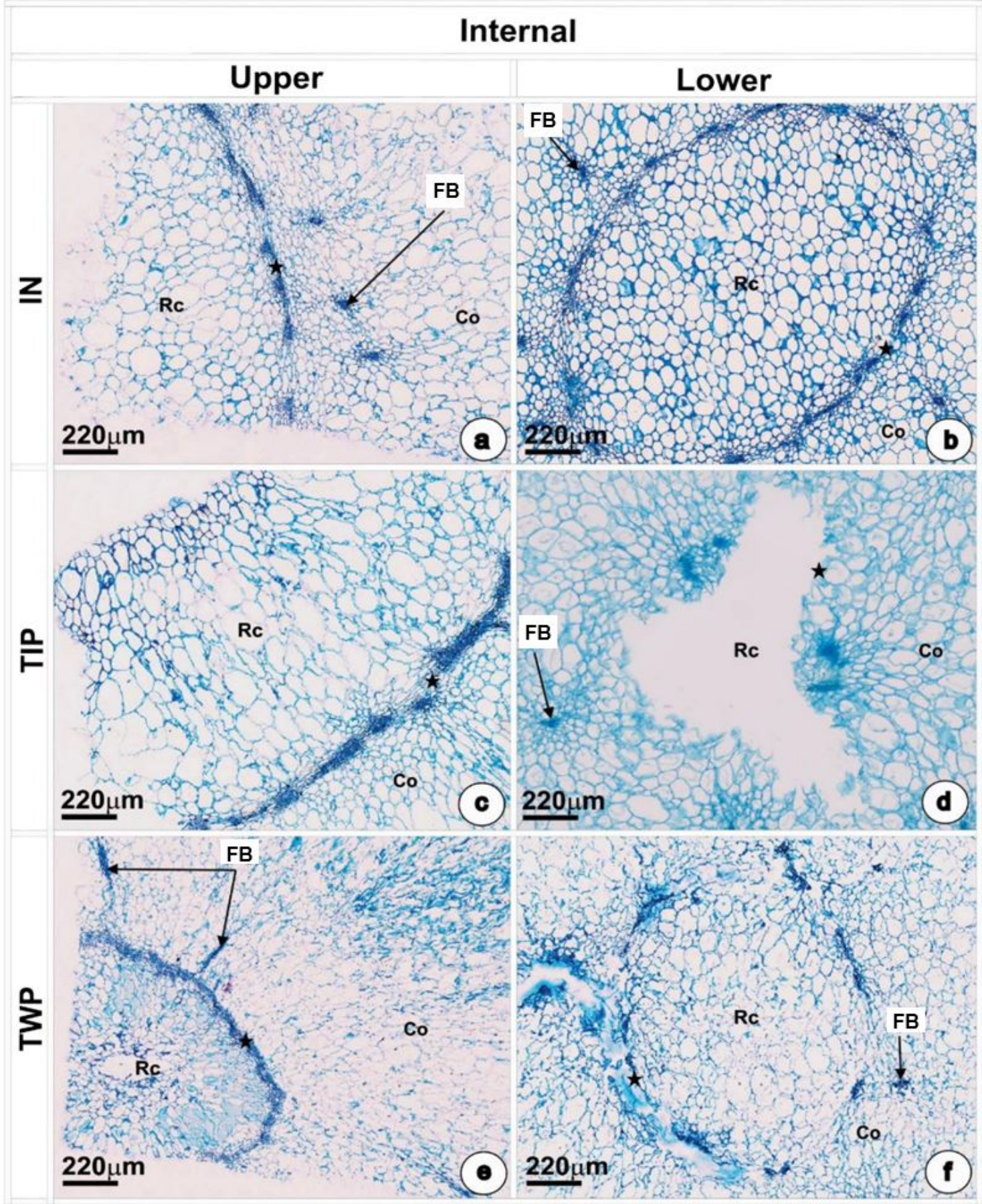

Figure 3. Internal view of the upper and lower sections of the in natura strawberry, with and without impregnation with antifreeze protein. a-f. Photomicrographs of strawberry transverse sections treated with Astra Blue (with primary blue wall) and Fuchsin (with secondary pink wall), fresh samples (a-b), samples impregnated with antifreeze protein (c-d), and samples without antifreeze protein (e-f). Samples a, $\mathbf{c}$ and $\mathbf{e}$ are from the upper part and samples $\mathbf{b}, \mathbf{d}$ and $\mathbf{f}$ are from the lower part. Caption: Co - cortex; FB - vascular bundle; Rc - region central; Star ( $\star$ ) - narrow zone of vascular bundle; IN - in natura; TIP - thawed infiltrated with protein; TWP - thawed without protein.

The in natura strawberry presented an intact structure. In general, the cells were not subjected to any treatment and the histological slides were prepared less than 24 hours after harvest, thus preserving the natural characteristics of the tissues and especially of the cells. The cells were globose, with their intracellular contents preserved. 
When observing the results for the sample of thawed strawberries without the antifreeze protein, the damage due to freezing was evident. The extent of the damage ranged from the tissues of the epidermis, through the cortex to the central region. The cells were degraded and lost their globose form, becoming wilted, which characterizes extravasation of the intracellular contents. The freezing of tissues occurs in different stages. The first ice crystals are formed by the moisture on the surface of the cell walls and then grow in the intracellular spaces. The small mass of ice acts as the condensation surface for the water, which migrates through the cell wall in response to the vapour pressure gradient.

As the ice crystals grow, the cells dehydrate and wrinkle. This process is not lethal, but when intracellular freezing occurs, the rupture also occurs in the cell nucleus and this process is always fatal (Chitarra \& Chitarra, 2005).

For the strawberry impregnated with the antifreeze protein, the result was satisfactory and evidenced the efficiency of the vacuum protein impregnation. For the most part, the cells of the thawed sample with the antifreeze protein remained intact, preserving the characteristics observed in the reference sample of the in natura strawberries. Thus the globosity of the cells indicates the preservation of their intracellular contents, which is important, given that the freezing technology applied tends to form large ice crystals, which would damage the cellular structures.

\section{Conclusion}

The characteristics of the hydroponic strawberries impregnated with the antifreeze protein remained very close to those of the in natura strawberries. Thus, the antifreeze protein was efficient in the structural conservation of this pseudo-fruit, even after being subjected to freezing. The vacuum impregnation process retained the parameter $\mathrm{a}^{*}$, which indicates chromaticity from green to red, so that the smaller size of the ice crystals formed did not rupture the plant cell and thus preserved the pigment. The lower drip loss in strawberries impregnated with the antifreeze protein demonstrated that there was no extravasation of the intracellular contents, which also contributed to the preserved colour characteristic.

\section{Acknowledgements}

This work was supported by CNPq-Brazil [grant number CNPq 443244-2014-6].

\section{References}

Brasil. (2008). Métodos físico-químicos para análise de alimentos (4. ed.). São Paulo: Ministério da Saúde.

Brasil. (2016). Regulamento técnico geral de padrões de identidade e qualidade para polpa de fruta. Brasília: Ministerio da Agricultura e Pecuaria.

Chisari, M., Barbagallo, R. N., \& Spagna, G. (2007). Characterization of Polyphenol Oxidase and Peroxidase and Influence on Browning of Cold Stored Strawberry Fruit. Journal of Agricultural and Food Chemistry, 55(9), 3469-3476. PMid:17407312. http://dx.doi.org/10.1021/jf063402k

Chitarra, M. I. F., \& Chitarra, A. B. (2005). Pós-colheita de frutas e hortaliças: fisiologia e manuseio (2. ed.). Lavras: UFLA.

Corel. (2017). CoreIDRAW graphics suite. Ottawa: Corel Corporation.

Cruz, R. M. S., Vieira, M. C., \& Silva, C. L. M. (2009). The response of watercress (Nasturtium officinale) to vacuum impregnation: Effect of an antifreeze protein type I. Journal of Food Engineering, 95(2), 339-345.

http://dx.doi.org/10.1016/j.jfoodeng.2009.05.013

Damodaran, S., Parkin, K. L., \& Fennema, O. R. (2010). Química de alimentos do Fennema (4. ed.). Porto Alegre: Artmed.

Fellows, P. J. (2006). Tecnologia do processamento de alimentos: princípios e práticas (2. ed.). Porto Alegre: Artmed.

Holzwarth, M., Korhummel, S., Carle, R., \& Kammerer, D. R. (2012). Evaluation of the effects of different freezing and thawing methods on color, polyphenol and ascorbic acid retention in strawberries (Fragaria ananassa Duch). Food Research International, 48(1), 241-248. http://dx.doi.org/10.1016/j.foodres.2012.04.004

Koblitz, M. G. B. (2008). Bioquímica de alimentos: teoria e aplicações práticas. Rio de Janeiro: Guanabara Koogan. 
Kraus, J. E., Sousa, H. C., Rezende, M. H., Castro, N. M., Vecchi, C., \& Luque, R. (1998). Astra blue and basic fuchsin double staining of plant materials. Biotechnic \& Histochemistry, 73(5), 235-243. PMid:9829416. http://dx.doi.org/10.3109/10520299809141117

Oetterer, M., Arce, M. A. B. R., \& Spoto, M. H. F. (2006). Fundamentos de ciência e tecnologia de alimentos. São Paulo: Manole.

Oliveira, R., \& Akisue, F. (2009). Fundamentos da farmacobotânica e de morfologia vegetal (3. ed.). São Paulo: Atheneu.

Oszmianski, J., Wojdylo, A., \& Kolniak, J. (2009). Effect of L-ascorbic acid, sugar, pectin and freeze-thaw treatment on polyphenol content of frozen strawberries. Food Science and Technology, 42, 481-586.

Pereda, J. A. O., Rodrígues, M. I. C., Álvarez, L. F., Sanz, M. L. G., Minguillón, G. D. G. F., Parales, L. H., \& Cortecero, M. D. S. (2005). Tecnologia de alimentos: componentes dos alimentos e dos processos. Porto Alegre: Artmed.

Provesi, J. G., \& Amante, E. R. (2015). Revisão: proteínas anticongelantes - uma tecnologia emergente para o congelamento de alimentos. Brazilian Journal of Food Technology, 18(1), 2-13. http://dx.doi.org/10.1590/1981-6723.7714

Reno, M. J., Prado, M. E. T., \& Resende, J. V. (2011). Microstructural changes of frozen strawberries submitted to pretreatments with additives and vacuum impregnation. Food Science and Technology, 31(1), 247-256. http://dx.doi.org/10.1590/S0101-20612011000100038

Velickova, E., Tylewicz, U., Rosa, M. D., Winkelhausen, E., Kuzmanova, S., \& Galindo, F. G. (2013). Effect of vacuum infused cryoprotectants on the freezing tolerance of strawberry tissues. Lebensmittel-Wissenschaft + Technologie, 52(2), 146-150. http://dx.doi.org/10.1016/j.Iwt.2011.09.013 